\title{
The Development of Community Economic System of Thung Kula Ronghai Farmers at Ban Ta Yuak, Northeastern Thailand
}

\author{
${ }^{1}$ Prasopsuk Rithidet, ${ }^{2}$ Preecha Piampongsan, ${ }^{3}$ Preecha prathepa, ${ }^{4}$ Boonsom Yodmalee \\ ${ }^{1}$ Faculty of Humanities and Social Science, Mahasarakham University \\ ${ }^{2}$ Mekhong Economic Faculty, Ubon Rachathani Rajabhat University \\ ${ }^{3}$ Faculty of Biotechnology, Mahasarakham University \\ ${ }^{4}$ Research Institute of N.E. Art and Culture, Mahasarakham University, Thailand
}

\begin{abstract}
The article was based on the case study at Ban Tayuak, Tambon Thung Luang, Amphoe Suwannaphum, Roi Et, Thung Kula Ronghai, N.E. Thailand By using qualitative research method, the researcher interviewed farmers who had been settled there over ten years. Field and documentary data were then analyzed. The results of the study were as follows: The area of thung Kula Ronghai has been occupied since the prehistoric period. Prehistoric and today's settlements are found at Ban Muang Bua and Ban Tha Nen, Amphoe Kasetwisai, Roiet; Ban ya Weuk, Amphoe chumponburi, Surin. The evidences found included rice, fish, Salt, and iron tools. As the new comers to the area, the people at Ban Ta yuak were themselves thai-Khmers and came from Amphoe Thathum, Surin looking for fertile land. The community economic systems were classified as traditional and newly developed ones. The traditional economic system existed before 1974 The newly developed one introduced during 1974 - 2003. The traditional economic system was subsistent depending upon family and clan labor, rain water, ancestral beliefs, and community exchange. The newly developed economic system was based on a single crop growing and chemical fertilizer. Such a market economy was partly introduced by the government during $1974-1997$ Unlike the traditional economic system, the market economy emphasized capital investment and pricing of which the farmers had no or little control. The commercial goods were nore expenive than the agricultural produces. As a result, the farmers spent more than their annual income earning. The System created poverty within village communities in thung Kula Ronghai region. The period of 1997 - 2003 the community developed an economic system of their own choice promoting participation and the pooling of natural resources, investment, technology, and local wisdom. They set up a silk making group. they marketed their own rice, silk cloth and dealt with Outside organizations carefully. They made sure that they could move along using their own pace, social and cultural strength, and flexibility amidst postmodernity.
\end{abstract}

Key words: The development of community economy, The Thung Kula Ronghai farmers' Community

\section{INTRODUCTION}

A major goal for human resource development is to achieve improved and suitable quality of life using self - learning process. They learn to give, think, and act practically and creatively. Through social, economic, cultural, and educational process, knowledge and skills are built leading to life quality improvement "The national economic power is the sum of the people's economic status ${ }^{[1]}$."

It is necessary to look in to detailed description of economic development of the farmers of Thung Kula Ronghai.
1. The Prehistoric Period Prehistoric evidences remained suggested that the Thung Kula Ronghai region was the land of rice, fish, salt, iron ${ }^{[2]}$.

2. Ban Ta Yuak Settlement. The people who first moved to Ban Ta Yuak came from Amphoe Ta Thum, Surin Some 200 years age. Their economy was subsistence by growing rice and using family labor. They also depended upon rain water, natural surroundings, such as, wood, water resources, beliefs and spirits. They did not depend of upon outsiders for support. Such a community - base economy remained efficient until 1974. ${ }^{[3]}$ The economy of Ban Ta yuak shifted to another system took place during 
1974 - 2003. Outside influences pierced in to the village community introducing chemical fertilizer, insect - pest control, mono - cropping, tools, and market. The farmers later realized that if they continued to practice or keep that system they could face a bigger economic and social loss than gain. The farmers then took up the self-support policy. They learned to choose what was or were useful for them. Those could be government or nongovernment. The social and economic strength achieved could be explained in relations to family, government non- government, media, and individuality.

1. Family. As a foundation of community, family at Ban Ta yuak plays an important role in transmitting skills and knowledge among family members benefiting everyone involved. Learning how to weave using cotton and silk threads practically began at home. Such a skill or knowledge were basically the family and community asset. Such could be further improved.

2. The Government. Ban Ta Yuak primary school took up the role of education in community development seriously by bringing school curriculum in various fields into practices. School rooms, silk thread, looms, weaving experienced villagers were provided. School children were allowed to take the weaving course of their own choice. The village also set up a weaving group using quality thread, better equipment, and community participation. The school, school children, the weaving group, and the community at large shared the learning experiences equally together.

3. The Non - government. The people at Ban Ta yuak kept to themselves the intention to go forward with silk and cotton cloth making. The savings Bank and the Supamit Foundation, each provided a 500,000 bath loan to the weaving group. It did not take very long for the group to pay back the loans. Their success owed the people support of non-government and government alike. The people themselves also displayed group loyalty, group CO-operation, and full participation of the community.

4. The Media. Adaptation is important for people everywhere duri the globalization period. The people at Ban Ta Yuak took adaptation seriously. They tried to blend with their immediate surroundings so that they could not only function but also master themselves socially and economically. They sent their village fellows or weaving group members for job or market training undertaken by government or nongovernment organizations. One member of weaving group learned about cloth designs from going from place to place selling the silk and or cotton cloth, meeting customers, or watching documentary programs on designs. The same was true for other villagers or group members. Some learned from the media how to dye cloth using chemical or natural dyes. What followed the success of the weaving group was the on coming to visit of media as well as the public and the interest group's of people. Their specially needs of finished product or suggestions concerning the product or activities were very valuable for the weaving group members. Some outsiders suggested some research work on improving the quality of silk cloth. Whatever new knowledge, information or suggestions may be, it was up to the people to choose what's best or suitable for them.

5. The Individuality. Individuality was important for social and economic strength of Ban Ta yuak. Members of the weaving group, for example, were divided in to 3 groups depending upon their weaving capacity, ranging from 5-10, 10-15, and 1520 pieces per month respectively. The pries of the silk cloth per piece were from $80-1000$ bath. The awarded - prices ever won for competition ranged from 10,000 - 30,000 Bath. The prices and awarded - prices made or gained paved way for further publicity and or market. At the time of conducting research, the income made from selling silk cloth was only second to rice. As far as identity was concerned, the cloth designs at Ban Ta Yuak were typically Khmer, known as, pha holl, seemed to have a profitable future.

\section{THE FARMERS' ADAPTATION}

Adaptation is necessary for everybody and occupations. For the period of 200 years the farmers at Ban Ta yuak learned how to survive amidst changes from all sides. They took a wrong step at a certain period, but as a whole they maintained own ethnic identity, They proved to themselves that they could survive capitalism. Their household or group product, such as, silk cloth was accepted nation-wide. Their silk cloth was accepted as a one Tambon One Product. The product was also accepted for competition under the Queen's project, "Silapacheep" The long - term adaptation of ban Ta Yuak silk weavers needed a variety of activities related to types, prices and quality, and market management. Each member of the weaving group made silk cloth for his or her family consumption and for market. A family of 6 could save the money between 14,000 - 22,000 Bath per year. The whole village of Ban Ta yuak could save some 500,000 - 1,280,000 bath. Income making for individual silk cloth weaver was also necessary for long-term adaptation so that he or she could have a sturdy income and fine quality of silk 
cloth. For business management, the weaving group members needed a workable marketing. By having a truck, the group sent their product of individual buyers or retail shops within the coping areas. Individual members, each made silk cloth of his or her own quantity and quality, gave their product to the marketing team whose 3 members dealt directly with customers and retail shops. The group took 3\% off the sale made of each group member. So that the group had some income for improvement to the group. The administrative team members operated on the first comes first serves basis. They treated one another equally regardless of kinship ties. As a results, the moral and market systems were used together. The group members had set a moral standard for doing business in the village community.

\section{CONCLUSION AND SUGGESTIONS}

Being the Khmer ethnic, the people at Ban Ta Yuak traditionally worked on their land growing rice and using family labor. They were subsistent farmers. As outside influences began to move in the village community, the farmers, more than ever, relied upon outside factors for farming as well as everyday life. They spent more than what they earned. Finally they came to a point that they should learn to blend with the outside world. They chose what was or were suitable for them they put more emphases on family, government and non-government support, media, and individuality. It worked. Weaving group members drew income from silk cloth making. They put some of their earnings for the management at the group, quality improvement, and quality of life of the people. Such took part in keeping the villagers at home rather than going to big cities hunting for employment. It was suggested that more effort should be put on local school curriculum of various fields or job training so that school children anal/ or adults could practically benefit from. By so doing, the development of community economy could be achieved at the grassroots quite sustainable.

\section{ACKNOWLEDGEMENTS}

The authors express their sincere appreciation for all of support provided

\section{REFERENCES}

1. Sanei Jarmarik, 1990. The participation of people in development. Bangkok: Foundation for Local Community Development.

2. Sujit Wongthate, 2003. The empire of Tung Kula 1957 from the backward era to the wealthy age of the Sweet Mali Rice age. Bangkok: Maticon press.

3. Chartthip Narthasupha and Punsak Chanikomprasit, 1997. An economic village on the south eastern coast in the past. Bangkok: Sarng San press. 